\title{
Türkiye'deki Bilgi ve Belge Yönetimi Bölümleri Ders Programlarının Düşünce Özgürlüğü Eğitimi Açısından Değerlendirmesi
}

\section{Evaluation of the Syllabi of Information and Records Management Departments in Turkey in Terms of Intellectual Freedom Education}

\author{
Meltem Dişli* ve Bülent Yılmaz**
}

$\ddot{O}_{z}$

Düşünce özgürlüğü, bilginin elde edilmesi, düzenlenmesi ve gereksinim duyanlara sunulması süreçlerinin bilimsel ve mesleki yöntemlerle gerçekleştirilmesine ilişkin bilgi ve becerilerin ögrencilere kazandırılmasını amaçlayan bilgi ve belge yönetimi eğitimi için temel etik çerçeve anlamina gelir. Bu nedenle, düşünce özgürlü̈̆̈̈ eğitimi bilgi ve belge yönetimi eğitiminin en önemli bileşenleri arasında yer alır. Bu çalışmanın amacı, Türkiye'deki Bilgi ve Belge Yönetimi $(B B Y)$ bölümlerinde verilmekte olan lisans ve lisansüstü eğitim içeriklerini ve uygulamalarını düşünce özgürlüğ̈ eğitimi bağlamında değerlendirmektir. Araştırma kapsamında, öncelikle 10 BBY bölümünde lisans ve lisansüstü programlarına ilişkin Bologna Bilgi (AKTS-ECTS) Paketlerinde yer alan tüm ders içerikleri incelenmiş, 9 bölümde düşünce özgürlüğ̈̈ ile ilişkili derslerin yer aldı̆̆g belirlenmiştir. Belirlenen 9 lisans ve 2 lisansüstü ders Bologna Bilgi Paketleri üzerinden içerik analizi yöntemi ile değerlendirilmiş, ayrıca bu dersleri veren ögretim üyelerinden 5'i ile görüşme yapılmıştır. Çalışma sonucunda, bölümlerde verilen düşünce özgürlüğüne ilişkin eğitimin bölümlerin politika ve yaklaşımlarına bă̆lı olarak bazı farklılıklar gösterdiği anlaşılmıştır. Çalışmadan elde edilen sonuçlar doğrultusunda konu ile ilgili bazı önerilerde bulunulmuştur.

Anahtar Sözcükler: Düşünce özgürlüğ̈̈; sansür; bilgi ve belge yönetimi ĕgitimi; kütüphanecilik eğitimi; düşünce özgürlüğ̈̈ eğitimi; kütüphanecilik ve düşünce özgürlügüu.

\begin{abstract}
Intellectual freedom means the basic ethical framework for information and records management education, which aims to provide students with the knowledge and skills related to the process of obtaining, organizing and presenting information to those who need it through scientific and professional methods. Therefore, intellectual freedom education is among the most important components of information and records management education. The purpose of this study is to evaluate content and practices in undergraduate and graduate education in Information and Records Management departments in Turkey, in the context of intellectual freedom education. Within the scope of the research, first of all, all course contents in the Bologna Information (ECTS) Packages of the undergraduate and graduate programs of 10

\footnotetext{
* Arş. Gör., Hacettepe Üniversitesi Bilgi ve Belge Yönetimi Bölümü. E-posta: meltem.disli@ hacettepe.edu.tr Research Ass., Hacettepe University Department of Information Management, Turkey.

** Prof. Dr., Hacettepe Üniversitesi Bilgi ve Belge Yönetimi Bölümü. E-posta: byilmaz@ hacettepe.edu.tr Prof. Dr., Hacettepe University Department of Information Management, Turkey.
}

Geliş Tarihi - Received: 17.08 .2020

Kabul Tarihi - Accepted: 19.11 .2020 
Türkiye’deki Bilgi ve Belge Yönetimi Bölümleri Ders Programlarının Düşünce Özgürlüğü Eğitimi Açısından Değerlendirmesi

Evaluation of the Syllabi of Information and Records Management Departments in Turkey in Terms of Intellectual Freedom Education

departments were examined, and it was determined that there were courses related to intellectual freedom in 9 departments. The determined 9 undergraduate and 2 graduate courses were evaluated by content analysis method through the Bologna Information Packages and also interviews with 5 of the lecturers who give these courses were conducted. As a result of the study, it was understood that the education on intellectual freedom given in departments showed some differences depending on the policies and approaches of the departments. In line with the results obtained through the study, some suggestions were made on the subject.

Keywords: Freedom of thought; intellectual freedom; censorship; information and records management education; education of librarianship; intellectual freedom education; librarianship and intellectual freedom.

\section{Giriş}

İnsanı diğer tüm canlılardan ayıran en önemli özelliği düşünebilen bir varlık olmasıdır. İnsanlar iyi veya kötü sürekli olarak düşünmekte ve düşündüklerini aktarmak istemektedirler. Çağdaş toplumlar, bireylere düşüncelerini başkalarına aktarabilmeleri için özgürlük sunmaktadır. Düşünce özgürlüğü yalnızca düşünceyi aktarmayı değil, aynı zamanda başkalarının düşüncelerine de özgürce erişebilmeyi gerektirmektedir. Yeni bilgiler edinmeden yeni düşüncelerin doğması olanaklı değildir. Bu konuda ise insanların bilgi ihtiyaçlarını karşılayan kurumlar olan bilgi merkezlerine büyük bir rol düşmektedir. Bilgi merkezleri hiçbir ayrım gözetmeksizin bireyleri bilgiyle buluşturan, böylece bireylerin yeni bilgiler 1şı̆̆ında yeni düşünceler üretmelerine doğrudan katkı sağlayan kurumlardır. İnsanların düşüncelerini geliştirebilecekleri, gereksinim duydukları bilgiye ulaşabilecekleri tarafsız kurumlar olan bilgi merkezlerinde de isteyerek veya istemeyerek bilgi kaynaklarına sansür uygulanabilmektedir (Fiske, 1959; Sağlamtunç, 1991, s. 95; Kızılkan, 1994, s. 22). Sansür, kütüphanelerde bilgi kaynaklarının seçiminden erişime sunulmasına kadarki sürecin her aşamasında söz konusu olabilmektedir. $\mathrm{Bu}$ nedenle bir toplumun özgürce bilgiye erişebilmesi ve özgürce düşünebilmesi toplumdaki bilgi profesyonellerinin düşünce özgürlüğüne bakış açısıyla yakından ilişkili görünmektedir.

Bilgi profesyonelleri toplumda düşünce özgürlüğünün gerçekleşmesi için mesleki çaba harcamalı, toplum ile bilgiyi buluşturmak için mesleki becerisini kullanmalı ve bu konuda ödün vermemelidir. Ancak bunun için öncelikle tüm bilgi profesyonelleri düşünce özgürlüğü kavramının önemini anlamış olmalıdır. Onlar, düşünce özgürlüğü ile bilgi merkezleri arasındaki karşlıklı ilişkiyi içselleştirmelidirler. Bilgi profesyonelleri her iki kavramın da birbiri için varlık nedeni olduğunu, düşünce özgürlüğü olmadan bilgi merkezlerinin ve bilgi merkezleri olmadan da düşünce özgürlüğünün olamayacağını temel bir ilke olarak kabul etmelidirler. Ancak bilgi profesyonelleri bazı durumlarda sansür uyguladığının farkında olmadan "iyi niyetli" uygulamalar ile halkın bilgiye erişmesini engelleyebilmektedir. İşte bu noktada bilgi profesyonelinin aldığı eğitim büyük önem taşımaktadır. Her ne kadar bilgi ile toplumu buluşturmak temel amaçları olsa da, düşünce özgürlüğü olgusunu tam olarak kavrayamamış bir bilgi profesyonelinin düşünce özgürlügü ilkesine dayalı bir hizmet vermesi beklenemez. 
$\mathrm{Bu}$ araştırmada bilgi profesyonellerinin lisans, yüksek lisans ve doktora eğitimleri boyunca düşünce özgürlüğü ile ilgili almış oldukları dersler ve ders içerikleri analiz edilmektedir. Araştırma kapsamında öncelikle düşünce özgürlügü ve sansür kavramları ile bilgi merkezleri-düşünce özgürlüğü ve bilgi ve belge yönetimi bölümleri-düşünce özgürlüğü ilişkilerine değinilmiştir. Daha sonra Türkiye'deki bilgi ve belge yönetimi bölümlerinin lisans, yüksek lisans ve doktora programlarında düşünce özgürlüğü konusunda verilen dersler incelenmiştir.

\section{Düşünce Özgürlüğü ve Sansür}

Düşünce özgürlüğü, düşünce ve özgürlük kavramlarından oluşmaktadır. Düşünce "çevreden edinilen algıların zihinde işlenmesi” (Alaca ve Yılmaz, 2015, s. 4), özgürlük ise "tam egemenlik hakkına sahip olma" (Gülle, 1997, s. 17) biçiminde tanımlanmaktadır. Bu doğrultuda düşünce özgürlüğü, insanın istediği konuda bağımsız bir şekilde düşünme hakkının olması ve düşüncelerini dilediği gibi ifade edebilmesi, hiçbir şekilde engellenmeden başka düşüncelere de erişebilme hakkının olması anlamına gelmektedir (Sağlamtunç, 1991, s. 93). Gülle’ye (1997, s. 18) göre düşünce özgürlüğü, düşüncenin ortaya çıkmasından insanlara bağımsız bir biçimde sunulmasına kadarki tüm süreci içeren evrensel ve çağdaş bir iletişim yöntemidir. Amerikan Kütüphane Derneği (American Libray Association, 2020) ise düşünce özgürlüğünü her bireyin hiçbir kısıtlama olmaksızın tüm bakış açılarına ait bilgileri arama ve bu bilgilere erişebilme hakkı olarak tanımlamaktadır. Çakmak ve Yılmaz (2012, s. 420) da düşünce özgürlüğünü, düşüncenin oluşumunu sağlayan tüm unsurlara hiçbir şekilde engellenmeden erişilebilmesi ve ortaya çıkan düşüncenin özgürce ifade edilebilmesi olarak tanımlamıştır. Bu tanımlardan yola çıkarak, düşünce özgürlügünü, bireylerin herhangi bir sebeple engellenmeden düşünebilmesi, düşüncelerini istedikleri ortamda açıklaması, paylaşabilmesi ve düşüncelere erişimin kısıtlanmaması biçiminde özetleyebiliriz.

Türkçe kaynaklarda "düşünce özgürlüğü” olarak geçen kavram, yabanc1 literatürde daha çok "intellectual freedom” (entelektüel özgürlük) olarak geçmektedir, yani "sorgulama, araştırma, eleştirme ve itiraz etme” gibi eylemlerin tamamıdır (Özışık, 2019, s. 124). Düşünce özgürlüğü kavramı aslında düşünme eyleminden de öte entelektüel özgürlük, kanaat özgürlüğü, bilgiye erişim özgürlüğü ve ifade özgürlüğünün bileşiminden oluşan çok daha geniş bir kavramdır (Sturges, 2016, s. 176). Oltmann'ın (2017, s. 749) çalışmasına göre ise düşünce özgürlüğü ile ilişkili en önemli kavramlar telif hakları, fikri mülkiyet hakları, intihal, mahremiyet, akademik özgürlük ve sansürdür.

Düşünce özgürlüğü düşüncenin oluşumu, dağıtımı ve düşünceye erişim aşamalarından oluşmaktadır. Bu aşamalardan biri olmazsa diğerleri de olmaz. Ekici ve Y1lmaz (2013, s. 18) düşünce özgürlüğü kavramının düşünme eylemine engel olunmaması, düşünme eyleminin sonucunda ortaya çıkan düşüncenin farklı yollarla ifade edilebilmesi ve bu düşünceye başkalarının erişiminin engellenmemesi durumlarını kapsadığını belirtmiştir. Bu kapsamda düşünce özgürlügü ifade özgürlügü, düşünme eyleminin engellenmemesi, düşüncenin özgürce iletimi ve erişimi, farklı düşüncelere saygı duyma, düşünceyi açıklamaya zorlanmama, düşünceden dolayı kınanmama ve dışlanmama gibi kavramları içermektedir (Alaca ve Yılmaz, 2015, s. 5). Bu kavramlardan birinin eksikliği diğerlerini de etkileyerek düşünce özgürlüğünü 
Türkiye'deki Bilgi ve Belge Yönetimi Bölümleri Ders Programlarının Düşünce Özgürlüğü Eğitimi Açısından Değerlendirmesi

Evaluation of the Syllabi of Information and Records Management Departments in Turkey in Terms of Intellectual Freedom Education

olumsuz yönde etkilemektedir. Düşünce özgürlüğünün engellendiği yerde sansür başlamaktadır.

Sansür, Türk Dil Kurumu'na (2020) göre "her türlü yayının, sinema ve tiyatro eserinin hükûmetçe önceden denetlenmesi işi, sıkı denetim" anlamına gelmektedir. Kızılkan (1988, s. 161) bilgi merkezleri açısından sansürü, yayınların yıpratılması, erişime sunulmaması, yasaklanması, saklanması, sınırlanması, etiketlenmesi ve ortadan kaldırılması gibi çabalar olarak tanımlamıştır. Amerikan Kütüphane Derneğine (American Libray Association, 2017) göre ise sansür belirli kişilerin, grupların veya devlet görevlilerinin sakıncalı veya tehlikeli buldukları fikir ve bilgileri bastırma çabasıdır. Daha çok devletin kamu yararını korumak amacıyla uyguladığı yöntemler olarak bilinmesine karşın Kızılkan (1994, s. 10) sansürün düşünce ürünlerine çeşitli sebeplerle kişi, grup ve kuruluşlar tarafindan da uygulandığını belirtmiştir. Çocuklara zarar verebilecek, bireyleri şiddete yönlendirebilecek, hakaret, aşağılama, küfür niteliğinde içeriklere sahip olan bazı düşünce ürünlerine sınırlamalar getirmek gerekli olmakla birlikte sansür ile düşünce özgürlüğünün sınırlarını çok iyi belirlemek gerekmektedir. Hiçbir düşünce ürünü dil, din, ırk, cinsiyet, etnik köken, siyasi görüş vb. ayrımlar gözeterek engellenmemelidir. Düşünce özgürlüğü hakkının engellenmesi yukarıda anılan hassas konular dışında hangi amaçla yapılırsa yapılsın bir insan hakkı ihlalidir.

\section{Bilgi Merkezleri ve Düşünce Özgürlüğü İlişkisi}

Düşünce özgürlüğü bilme eylemiyle doğrudan ilgilidir. Bilgi kaynaklarına erişemeyen, yeni bilgiler edinemeyen insanın yeni düşünceler ortaya çıkarması olanaklı değildir. Kütüphane, arşiv, dokümantasyon merkezi ve müzeler gibi bilgi merkezleri toplumu bilgiye eriştiren kurumlar olarak düşünce özgürlüğünü beslemektedir. Alaca ve Yılmaz’a (2015, s. 3) göre, kullanıcı bilgi kaynağına eriştikçe kendisini geliştirmekte, bilinçlenmekte, ileriyi görebilmekte ve düşünebilme yeteneğini kazanabilmektedir. Çelik ve Tonta (1996, s. 2) ise yeterli bilgiye erişemeyen bireylerin özgür davranamadıklarını belirtmekte ve bilgi edinme özgürlüğü ile düşünce özgürlüğü arasındaki güçlü ilişkiye vurgu yapmaktadır. Bilgi merkezleri, kullanıcının bilgi edinme özgürlüğünü göz önüne alarak hizmetler sunması ve kullanıcı ile bilgiyi buluşturması açısından düşünce özgürlüğünün oluşması ve gelişmesinde en önemli role sahip toplumsal kurumlardır. Düşünce özgürlüğü kapsamında kütüphanelerde bilgi kaynakları, içeriğine önyargıyla yaklaşmadan, erişimi kısıtlamadan ve ayrım yapmadan herkese eşit bir şekilde sunulmalı; kullanıcıların kişilik hakları korunmalı, kullanıcının özgürce araştırma yapabilmesi ve bilgilerinin gizli tutulması sağlanmalı; kullanıcıların yaptıklarıyla ilgili bir fikirde bulunulmamalı ve kütüphaneciler kullanıcıyı etkilememelidir (Çelik ve Tonta, 1996, s. 8).

Bilgi merkezleri her türlü bilgi kaynağını tarafsız bir şekilde sağlamak ve bu bilgi kaynaklarını din, dil, ırk, yaş ve siyasal görüş ayrımı gözetmeksizin herkese eşit bir şekilde sunmak, adil hizmeti güvence altına almakla yükümlüdür (Kızılkan, 1988, s. 163). Bu görevleri bilgi merkezlerini bilgi edinme özgürlüğü, bilgiye erişim ve düşünce özgürlüğü konularında önemli bir konuma getirmektedir. Farklı görüşlerden bilgi kaynaklarına özgürce erişen ve farklı fikirleri öğrenen bireyler daha özgür bir toplumu oluşturmaktadır. Sağlamtunç (1991, s. 93) da 
kütüphanecilik mesleğinin toplumdaki bireylere düşünce özgürlüğünü sağlama sorumluluğuna dikkat çekmiştir.

Kütüphanecilik ve bilgi bilim alanında düşünce özgürlüğü ile ilgili çeşitli bildirgeler yayınlanmış ve ilkeler belirlenmiştir. Bu alanda ilk çalışmalar Amerikan Kütüphane Derneği tarafından gerçekleştirilmiştir. Amerikan Kütüphane Derneğinin 1939 yılında hazırladığ 1 ve en son 2019 yılında güncellenen “Kütüphane Hakları Bildirgesi” kütüphane ve bilgi bilim alanı için en önemli çalışmalardandır. Bildirge'ye (American Library Association, 2019) göre hiçbir bilgi kaynağı yaratıcısının kökeni veya görüşleri sebebiyle dışlanmamalı, kütüphaneler tüm bakış açılarına yönelik bilgi kaynağına yer vermeli, sansüre meydan okumalı, ifade özgürlüğü ve bilgiye serbestçe erişim konularında kişi veya gruplarla işbirliği yapmalı, kimsenin kütüphaneyi kullanma hakkı yaş, ırk, din, ulusal köken, siyasal veya toplumsal görüşleri nedeniyle kısıtlanmamalı, sergi alanı ve toplantı salonları adil bir şekilde kullanıma açılmalı, kütüphaneler ne olursa olsun kullanıcıların mahremiyetini korumalıdır.

1967'de Düşünce Özgürlüğü Ofisi'ni kuran Amerikan Kütüphane Derneği kütüphanecileri düşünce özgürlüğü kavramı konusunda eğitmeyi amaçlamıştır. ALA bu amaçla konferanslar düzenlemek, kütüphanecilere danışmanlık yapmak gibi çeşitli çalışmalar yapmaktadır (Kızılkan, 1988, s. 164). Düşünce Özgürlüğü Ofisi tarafından hazırlanan Düşünce Özgürlüğü El Kitabı da düşünce özgürlüğü ve sansür konularını ele almaktadır (American Library Association, 2015).

Uluslararası Kütüphane Dernekleri ve Kuruluşları Federasyonunun (IFLA) Bilgi ve Düşünce Özgürlüğü'ne Serbest Erişim Komitesi (FAIFE) adıyla kurduğu komite ifade özgürlüğü ve iyi kütüphaneciliğin ilkelerini belirlemiştir. En son 2016 yılında güncellenen ilkeler Türk Kütüphaneciler Derneği tarafından Türkçe'ye çevrilerek kamuoyuna sunulmuştur (IFLA, 2016; Türk Kütüphaneciler Derneği, 2019). Bu ilkelere göre kütüphaneler bilgi, düşünce ve kültüre erişim imkânı sunan; düşünce özgürlüğünün gelişimine ve korunmasına katkıda bulunan kurumlardır. Kütüphanelerin ifade özgürlüğünü koruma ve kolaylaştırma sorumlulukları bulunmaktadır. Kütüphanelerde kullanıcılar özgürce iletişim kurabilmeli ve düşüncelerini ifade edebilmelidir. Kütüphanelerde kütüphane materyalleri ve hizmetleri siyasi, ahlaki ve dini görüşler sebepleriyle kısıtlanmamalı ve sansürlenmemelidir. Kütüphane materyallerinin seçimi ve hizmete sunulmasında da siyasi, ahlaki ve dini görüşler etkili olmamalıdır. Kütüphaneler özgür bir şekilde sağladığı bilgileri düzenleme ve kullanıcıya sunma süreçlerinde her türlü sansürün karşısında durmalıdır. Kütüphaneler hizmet sundukları kullanıcılarına ırk, din, cinsiyet, yaş gibi sebeplerle ayrım yapmamalıdır. Kütüphaneciler kullanıcıların kişisel mahremiyet hakkına saygı duymalı ve bilgilerini üçüncü şahıslara açıklamamalıdır.

Türkiye'de ise Türk Kütüphaneciler Derneği (TKD) tarafından 2008 yılında “Düşünce Özgürlüğ̈̈ Bildirgesi" hazırlanmıştır (Türk Kütüphaneciler Derneği, 2008). TKD Düşünce Özgürlüğ̈̈ Bildirgesi'nde de uluslararası bildirgelerdeki ilkelere benzer ilkeler yer almaktadır. $\mathrm{Bu}$ bildirgeye göre, bilgi merkezleri politika geliştirme aşamalarında düşünce özgürlüğünü benimsemelidir. Bilgi merkezleri bireylerin bilgiye eşit ve özgürce erişim hakkını desteklemeli, düşünce ürünlerine erişmelerini dinsel, ırksal, ticari, siyasi, ahlaki, etnik köken, cinsiyet ve benzeri nedenlerle engellememeli ve sansüre karşı çıkmalıdır. Materyal seçiminde kütüphanecinin kişisel tercihleri, materyalin içeriği, yazarı veya yayıncısının düşünce, inanç ve 
Türkiye’deki Bilgi ve Belge Yönetimi Bölümleri Ders Programlarının Düşünce Özgürlüğü Eğitimi Açısından Değerlendirmesi

Evaluation of the Syllabi of Information and Records Management Departments in Turkey in Terms of Intellectual Freedom Education

görüşleri etkili olmamalıdır. Teknik hizmetler ve kullanıcı hizmetlerinde de erişimi engelleyen veya kısıtlayan uygulamalardan kaçınılmalıdır. Kullanıcıların kişisel mahremiyetine saygı duyularak bilgileri üçüncü şahıslarla paylaşılmamalıdır. Bilgi merkezi çalışanları bu Bildirge'nin ilkelerine aykırı davranmaya zorlanamazlar. Türk Kütüphaneciler Derneği'nin hazırlamış olduğu Mesleki Etik İlkeleri'nde de Düşünce Özgürlüğ̈̈ Bildirgesi'nde yer alan ilkelere uyulması gerektiği belirtilmiştir (Türk Kütüphaneciler Derneği, 2010).

Kütüphanecilik ve bilgi bilim alanında düşünce özgürlüğü ile ilgili hazırlanan kılavuz, bildirge ve ilkeler kütüphanecilere yol göstermekte ancak kütüphanecilere eğitim aşamalarında düşünce özgürlüğüne yönelik bilinç kazandırma konusunda Bilgi ve Belge Yönetimi Bölümlerine büyük görevler düşmektedir.

\section{Bilgi ve Belge Yönetimi Bölümlerinde Düşünce Özgürlüğüne Yönelik Eğitim}

Toplumu bilgi ile buluşturan bilgi merkezleri içinde bulunduğumuz bilgi çağının vazgeçilmez kurumlarıdır. Tarafsız ve doğru bilgiye hiçbir ayrım gözetmeksizin herkesin eşit biçimde erişebilmesini sağlayan bilgi merkezleri; toplumun farklı görüşleri öğrenmesine, bu görüşlere sayg1 duymasına, çok yönlü bilgilenmesine, böylece çağdaş ve hoşgörülü bir toplum yaratılmasına katkıda bulunmaktadır. Çağdaş toplumlarda gelişebilen düşünce özgürlüğü olgusu kütüphane, arşiv, müze gibi bilgi merkezleri tarafindan desteklendikçe büyümektedir. Bilgi merkezlerinde düşünce özgürlüğüne uygun bir ortam sunulması konusunda kütüphanecilere ve bilgi profesyonellerine önemli görevler düşmektedir. Bilgi merkezleri bu konudaki işlevlerini yerine getirdikçe toplum tarafindan da saygı duyulan ve benimsenen kurumlar olmaktadır. Bu saygınlığın kazanılmasında kültürlü, tarafsız, bilinçli ve mesleki ilkelerine bağlı bilgi profesyonellerinin olması büyük önem taşımaktadır. Bu bağlamda bilgi profesyonellerini bu niteliklerle donatacak olan Bilgi ve Belge Yönetimi Bölümleri ve bu bölümlerde verilen eğitimin rolü göz ardı edilemez (Kızılkan, 1994).

Sağlamtunç’a (1991, s. 95) göre, düşünce özgürlüğüne yönelik yeterli bilinç düzeyine erişemeyen kütüphaneciler yasal olarak yasak olmasa bile bir sorunla karşılaşmamak adına bazı bilgi kaynaklarını kütüphaneye sağlamayarak veya raflardan kaldırıp saklayarak otosansür uygulamaktadır. Kütüphanelerdeki sansür örneklerine bakıldığında bilgi kaynaklarının seçim sürecinde sansür uygulanmasının yanı sıra kütüphanecinin beğenmediği kaynakları hizmete geç sunması, sınıflama işlemlerinin yanlış yapılarak erişimin engellenmesi, danışma hizmetlerinde taraflı tutumlar sergilenmesi gibi birçok alanda sansür uygulandığı görülmektedir (Kızılkan, 1994, s. 22). Fiske de raporunda kütüphanecilerin kitap seçiminde otosansür uyguladığını ve taraflı davrandıklarını belirtmiştir (Fiske, 1959'dan aktaran Kızılkan, 1994, s. 26). Bilgi merkezlerinde derme geliştirme, bilginin düzenlenmesi, ödünç verme hizmetleri, danışma hizmetleri ve personel politikasında da sansür uygulanabilmektedir. Kütüphaneci derme geliştirme süreçlerinde üst yönetimden çekindiği için bazı bilgi kaynaklarını dermeye dahil etmeyerek, kendi beğenmediği kaynakların kataloglama ve sınıflama işlemlerini yanlış veya geç gerçekleştirerek, bilgi kaynağını ödünç almak isteyen kullanıcıyı "korumak" adına "iyi niyetli" uyarılarda bulunarak bilinçli veya bilinçsiz bir şekilde sansür uygulamaktadır. Canata (2016, s. 623) kütüphanecilerin bilinçlendirilmesi, düşünce özgürlüğünden yana ve sansüre 
karşı tutum alabilmesi konularında bilgi ve belge yönetimi eğitiminin önemine vurgu yapmıştır. Berninghausen'e (Berninghausen, 1969'dan aktaran Kızlkan, 1994, s. 27) göre ise kütüphanecilik düşünce özgürlüğünü ilke edinen bir meslektir ve bunun benimsetilmesinde en büyük sorumluluk kütüphanecilik bölümü öğretim üyelerindedir. Alberta Üniversitesi Kütüphane ve Bilgi Çalışmaları Bölümü Başkanı Prof. Dr. Tony Samek (2001, s. 42) de düşünce özgürlüğü dersleri sayesinde öğrencilerin düşünce özgürlüğünün karmaşıllğı ve çok boyutlu olması açısından farkındalıklarının arttı̆ıını, mesleki sorunları eleştirel olarak değerlendirebildiklerini, kütüphanelerin felsefe, hukuk, siyaset gibi farklı alanlar ile ilişkisini analiz edebildiklerini belirtmiştir.

Düşünce özgürlüğ̈nün kütüphanecilik eğitimine dahil edilmesi ilk olarak Amerika Birleşik Devletleri'nde gerçekleşmiştir. 1925 yılında ALA (Amerikan Kütüphane Derneği) kütüphanecilik okullarında akreditasyon programını uygulamaya koymuş ve daha sonra meslekte kuramsal eğitim öne çıkmıştır. 1968 yılında Simmons Koleji Kütüphanecilik Okulunda düşünce özgürlüğü ile ilgili ilk bağımsız ders olan "düşünce özgürlüğü ve sansür" dersi verilmeye başlanmışı̧ı (Kızılkan, 1994, s. 26). Yaklaşıı on yıl sonra yapılan Shuman'ın (1977, s. 99) çalışmasında Amerika'da az sayıda kütüphanecilik bölümünde düşünce özgürlüğüne yönelik doğrudan bir ders olduğu ancak hemen hemen tüm okullarda konunun müfredatta yer aldığı saptanmıştır. Ayrıca çalışma öğretim elemanlarının düşünce özgürlüğü konusunu müfredattaki çoğu derste değinilmesi gereken bir konu olarak değerlendirdiğini ortaya çıkarmıştır. Japonya'daki kütüphanecilik bölümlerinde düşünce özgürlüğü eğitiminin incelendiği bir çalışmada ise öğretim elemanları çoğunlukla düşünce özgürlüğüne yönelik bir ders olmas1 gerektiğini savunmuştur (Asato, 2014, s. 1). Günümüzde kütüphanecilik ve bilgibilim alanında eğitim veren bölümlerde düşünce özgürlüğü ve sansür konuları bağımsız bir ders olarak verilmese bile farklı derslerin içinde işlenmektedir. Alberta Üniversitesi'nde "Kütüphanecilikte Entellektüel Özgürlük ve Sosyal Sorumluluk" ismiyle verilen ders entelektüel özgürlük ve sosyal sorumluluk temel kavramlarını ve farklı türlerdeki kütüphaneleri etkileyen ilgili konuları incelemektedir (University of Alberta, 2020). San Jose Eyalet Üniversitesi’nde entelektüel özgürlük konularına ve entelektüel özgürlügün kütüphanecilik ile ilişkisine odaklanan "Entelektüel Özgürlük Semineri" dersi verilmektedir. Ayrıca "Çocuk ve Genç Yetişkinlere Hizmet Semineri" adındaki derste entelektüel özgürlük konularına değinilmektedir (San Jose State University, 2020). İndiana Üniversitesi'nde de "Entelektüel Özgürlükte Seminer" adıyla bağımsız bir ders bulunmaktadır (Indiana University, 2020). Toronto Üniversitesi'nde düşünce özgürlüğü ve sansür ile ilgili “Kütüphanelerde Entelektüel Özgürlük Teorisi ve Uygulaması" adıyla bağımsız bir ders bulunmakla birlikte "Topluluklar ve Değerler", "Kuram ve Uygulamada Sanat Kütüphaneciliği”, "Bilgi Politikası, Düzenleme ve Hukuk", "Bilgi Profesyonelliğinde Çeşitlilik Zihniyetinin Geliştirilmesi" isimli derslerde de ilişkili konular işlenmektedir (Toronto University, 2020). Derslerin isimlerinde farkl1lıklar olduğu gibi öğretim üyelerinin konuya yaklaşımlarında ve derslerde kullandıkları öğretim yöntemlerinde de farklılıklar bulunmaktadır. Asato'nun (2014, s. 6) çalışmasına göre düşünce özgürlüğü konusuna yönelik öğretim yöntemleri Amerika'da daha çok pratik yaklaşımlar içerirken, Japonya'da teorik yaklaşımlar içermektedir. Bu çalışmada öğretim yöntemlerinin öğrencilerin vaka çalışmaları yapmaları, gazetelerdeki olayları incelemeleri, dizi ve filmlerdeki olayları değerlendirmeleri gibi çeşitli uygulamalarla da farklılaştığı görülmektedir. 
Türkiye'deki Bilgi ve Belge Yönetimi Bölümleri Ders Programlarının Düşünce Özgürlüğü Eğitimi Açısından Değerlendirmesi

Evaluation of the Syllabi of Information and Records Management Departments in Turkey in Terms of Intellectual Freedom Education

Türkiye'de bilgi ve belge yönetimi bölümlerinde düşünce özgürlüğü ve sansür konuları genellikle meslek etiği derslerinin içinde işlenmekte, bazı üniversitelerde ise lisansüstü düzeylerde bağımsız dersler bulunmaktadır. Bu çalışmada düşünce özgürlüğüne yönelik olarak Türkiye'deki bilgi ve belge yönetimi bölümlerinde verilen dersler ve içerikleri ayrıntılı bir biçimde incelenmiş, farklılıklar ortaya konmaya çalış1 1 ış̧tır.

\section{Araştırmanın Amacı, Kapsamı, Yöntemi}

$\mathrm{Bu}$ araştırmanın amacı, geleceğin bilgi profesyonellerini yetiştiren Bilgi ve Belge Yönetimi bölümlerinin ders programlarını düşünce özgürlüğü bağlamında incelemektir. Araştırmada bölümlerin düşünce özgürlüğü ile ilgili hangi derslerde, nasıl bir içerik ile eğitim verdiklerini ortaya koymak ve bu kapsamda eksiklikleri belirlemek hedeflenmiştir. Türkiye'deki Bilgi ve Belge Yönetimi bölümlerinde düşünce özgürlüğüne yönelik verilen eğitimin içerik ve kapsamının belirlenmesinin, bölümlere düşünce özgürlüğü ile ilgili eğitimin geliştirilmesi açısından yardımcı olması beklenmektedir. Bu doğrultuda aşağıdaki araştırma sorularına Türkiye bağlamında yanıt aranmıştır:

S1: Bilgi ve Belge Yönetimi Bölümlerinde düşünce özgürlüğü konusunda verilen eğitim bölümlere göre farkll1lklar göstermekte midir?

S2: Bilgi ve Belge Yönetimi Bölümlerinde düşünce özgürlüğü konusunda verilen eğitimde bölümlere göre hangi açılardan farklılıklar vardır?

S3: Bilgi ve Belge Yönetimi programlarında doğrudan düşünce özgürlüğüne yönelik bir ders bulunmakta midir?

S4: Düşünce özgürlüğü ile yakından ilişkili olan etik derslerinin içeriğinde düşünce özgürlüğü konusu yer almakta mıdır?

S5: Düşünce özgürlüğü konusuna hangi derslerde, ne kadar ve hangi bağlamda değinilmektedir?

S6: Öğretim üyelerinin Bilgi ve Belge Yönetimi eğitiminde düşünce özgürlüğü konusu ile ilgili yaklaşımları ve konuya ilişkin derslerde kullandıkları öğretim yöntemleri nasıldır?

Türkiye'de 2019-2020 eğitim-öğretim döneminde Bilgi ve Belge Yönetimi bölümü bulunan üniversiteler şunlardır:

- Adana Bilim ve Teknoloji Üniversitesi

- Ankara Üniversitesi

- Atatürk Üniversitesi

- Bartın Üniversitesi

- Çankırı Karatekin Üniversitesi

- Hacettepe Üniversitesi
- İstanbul Üniversitesi

- İstanbul Medeniyet Üniversitesi

- İzmir Katip Çelebi Üniversitesi

- Kastamonu Üniversitesi

- Marmara Üniversitesi

- Osmaniye Korkut Ata Üniversitesi

- Yıldırım Beyazıt Üniversitesi 
Araştırmanın gerçekleştirildiği 2019-2020 eğitim-öğretim döneminde öğrenci alımına başlamayan Adana Bilim ve Teknoloji, İzmir Katip Çelebi ve Bartın üniversiteleri çalışmaya dâhil edilmemiştir. Bu çalışmanın amacı, Türkiye'deki Bilgi ve Belge Yönetimi bölümlerinde verilmekte olan lisans ve lisansüstü eğitim içeriklerini ve uygulamalarını düşünce özgürlüğü eğitimi bağlamında değerlendirmektir. Araştırmanın problemi, "Bilgi ve Belge Yönetimi Bölümlerinde düşünce özgürlügü konusunda verilen eğitim bölümlere göre farkl1lıklar göstermekte midir?” biçiminde oluşturulmuştur. Bu probleme bağlı olarak, araştırmanın hipotezi de şöyledir: “Türkiye'deki Bilgi ve Belge Yönetimi bölümlerinde düşünce özgürlüğü konusunda verilen eğitim, bölümlerin yaklaşımlarına (politikalarına) bağlı olarak farklılıklar göstermektedir.” Bölümlerdeki farklılıklar derslerin AKTS, kredi ve sınıf bilgileri, amaçları, içerikleri, yöntem ve teknikleri, derslerden elde edilecek kazanımlar ve ders sorumlularının düşünce özgürlüğü konusuna yaklaşımları kapsamında incelenmiştir.

Betimleme yöntemine dayalı olarak gerçekleştirilen araştırmada yazılı verilerdeki içerik ve mesajların analiz edilmesi, incelenmesi, özetlenmesi ve raporlanması süreci olarak tanımlanan içerik analizi yöntemi de kullanılmıştır (Cohen, Manion ve Morrison, 2007, s. 475).

\section{Verilerin Toplanmast}

Verilerin toplanmasında üniversitelerin Bologna bilgi paketlerinden yararlanılmıştır. Bologna bilgi paketleri üniversitelerde verilen, bir başka deyişle ders programlarında yer alan derslerin içerik ve kapsamlarını standart bir biçimde tanımlamaktadır. Bologna bilgi paketleri ile ilgili olarak zaman zaman güncellik sorunları yaşansa da ders içerik ve amaçlarına erişim açısından en uygun araçtır. Araştırma kapsamında her bölümün lisans ve lisansüstü programları için Bologna bilgi paketleri elde edilmiştir. Bölümlerin Bologna (AKTS) bilgi paketleri ders programlarında yer alan tüm derslerin içeriklerini kapsadığından, araştırmada ders programlarının incelenmesi de bilgi paketleri aracılığıyla gerçekleştirilmiştir. Tüm dersler tek tek incelenerek içerik, amaç ve kazanımlarında düşünce özgürlüğü kavramı ile telif hakları, sansür, bilgi erişim özgürlüğü, bilgi edinme hakkı gibi ilişkili konular içeren dersler belirlenmiştir. Bologna bilgi paketlerinde yer almasa da düşünce özgürlüğü konusuna değinilen dersler olması mümkündür. Ancak içerik ve amacında düşünce özgürlüğü ile ilgili her hangi bir ifadeye yer verilmesine gerek duyulmayan/yer verilmeyen derslerde konunun içeriğe dâhil edilmeyeceği ya da konuya özel olarak/anlamlı ölçüde ağırlık verilmeyeceği dikkate alınarak araştırma kapsamına yalnızca bilgi paketlerinde düşünce özgürlüğü ve ilgili konular bulunan dersler dâhil edilmiştir. Araştırma kapsamında düşünce özgürlüğü ve ilişkili kavramlara lisans programlarında sadece mesleki etik derslerinde, lisansüstü programlarda etik ve düşünce özgürlüğü derslerinde değinildiği görüldüğünden araştırmada bu dersler incelenmiştir.

Düşünce özgürlüğü ile ilgili derslerin AKTS, Kredi ve Sınıf bilgileri, derslerin amaç ve içerikleri, derslerde kullanılan öğretim yöntem ve teknikleri, derslerden elde edilecek kazanımlar ayrı ayrı Excel'de listelenmiştir. Elde edilen veriler düzenlendikten sonra analiz aşamasına geçilmiştir. Bu çerçevede öncelikle Bologna bilgi paketlerinin ele alınan konu açısından içerik incelemesi gerçekleştirilmiş, ayrıca düşünce özgürlüğü ile ilişkili olduğu belirlenen derslerden sorumlu öğretim üyelerinin 5'i (Çankırı Karatekin Üniversitesi, Hacettepe Üniversitesi, İstanbul Üniversitesi, Kastamonu Üniversitesi, Osmaniye Korkut Ata Üniversitesi) ile 2019 yılı Aralık ayında görüşmeler yapılmıştır. 
Türkiye'deki Bilgi ve Belge Yönetimi Bölümleri Ders Programlarının Düşünce Özgürlüğü Eğitimi Açısından

Değerlendirmesi

Evaluation of the Syllabi of Information and Records Management Departments in Turkey in Terms of

\section{Verilerin Analizi}

Bologna bilgi paketleri ve öğretim üyeleriyle yapılan görüşmeler sonucunda elde edilen veriler ayrı ayrı incelendikten sonra tek biçim haline getirilerek özetlenmiştir. Böylece her bölümün ders içeriklerinin, amaçlarının, yöntem ve kazanımlarının bir arada görülebilmesi ve karşılaştırılabilmesi amaçlanmıştır.

\section{Sinırlılıklar}

Çalışmanın temel veri kaynağını oluşturan Bilgi ve Belge Yönetimi Bölümlerinin Bologna bilgi paketlerinde aynı düzeyde ayrıntılı bilgi verilmemesi, bilgi paketlerinin sıklıkla güncellenmemesi ve bilgi paketlerinde bazı eksiklikler olması araştırmanın sınırlılıkları olarak kabul edilebilir. Ancak bu sınırlılıklar ilgili ders sorumluları ile yapılan görüşmeler yoluyla aşılmaya çalışılmıştır.

\section{Bulgular ve Değerlendirme}

Bu bölümde Türkiye'deki Bilgi ve Belge Yönetimi bölümlerinde düşünce özgürlüğü ile ilgili verilen eğitim içeriği incelenmiştir. Bu doğrultuda öncelikle bölümlerin öğrenci ve öğretim elemanı sayıları gösterilmiştir. Düşünce özgürlüğü ile ilişkili dersler belirlendikten sonra bu derslerin amaç, içerik, öğretim yöntem ve teknikleri, derslerden kazanımlar değerlendirilmiştir. Son olarak öğretim üyelerinin konu ile ilgili görüşlerine yer verilmiştir.

\section{Bölümler ile İlgili Bulgular}

Bölümlerin öğrenci sayıları, öğretim elemanı sayıları, lisansüstü eğitimi veren bölümler ile ilgili bilgiler bu bölümde yer almaktadır.

\section{Tablo 1}

Son 3 yılda Bilgi ve Belge Yönetimi bölümlerine yerleştirilen öğrenci sayısı

\begin{tabular}{lrrr}
\hline Bölümler & 2017 & 2018 & 2019 \\
\hline Ankara Üniversitesi & 30 & 30 & 41 \\
Ankara Yıldırım Beyazıt Üniversitesi & 52 & 52 & 52 \\
Atatürk Üniversitesi & $62+62$ (̇̈.Ö.) & $62+14$ (İ.Ö.) & $62+31$ (İ.Ö.) \\
Çankırı Karatekin Üniversitesi & $62+62$ (̇̈.Ö.) & $29+13$ (İ.Ö.) & 52 \\
Hacettepe Üniversitesi & 71 & 71 & 72 \\
İstanbul Üniversitesi & $61+62$ (İ.Ö.) & 82 & 82 \\
İstanbul Medeniyet Üniversitesi & 41 & 52 & 52 \\
Kastamonu Üniversitesi & 61 & 36 & 62 \\
Marmara Üniversitesi & 62 & 62 & 63 \\
Osmaniye Korkut Ata Üniversitesi & 40 & 38 & 45 \\
\hline Toplam & 728 & 541 & 614 \\
\hline
\end{tabular}

Tablo 1'de Bilgi ve Belge Yönetimi bölümlerine son 3 yılda yerleştirilen öğrenci sayıları yer almaktadır. Son 3 yılda bölümlere yapılan öğrenci alımlarında çok fazla artış veya azalma olmamıştır. 2019-2020 Eğitim-Öğretim yılında bölümlere toplam 614 öğrenci alınmıştır. İkinci öğretimi de olduğu için en fazla Atatürk Üniversitesi’ne öğrenci alındığ1 görülmektedir (62 birinci öğretim, 31 ikinci öğretim olmak üzere 93 öğrenci). Bunu 82 öğrenci 
ile İstanbul Üniversitesi, 72 öğrenci ile Hacettepe Üniversitesi takip etmektedir. En az öğrenci alan üniversiteler Ankara Üniversitesi (41) ve Osmaniye Korkut Ata Üniversitesi (45)'dir. Bazı bölümlerde diğerlerinin iki katı kadar fazla öğrenci olması dikkat çekicidir.

Tablo 2

Lisansüstü eğitim veren üniversiteler

\begin{tabular}{ll}
\hline Bölüm & Program \\
\hline Ankara Üniversitesi & Yüksek Lisans, Doktora \\
Atatürk Üniversitesi & Yüksek Lisans \\
Hacettepe Üniversitesi & Yüksek Lisans, Doktora \\
İstanbul Üniversitesi & Yüksek Lisans, Doktora \\
Marmara Üniversitesi & Yüksek Lisans, Doktora \\
\hline
\end{tabular}

Türkiye'de Tablo 2'de isimleri verilen beş üniversitede bilgi ve belge yönetimi alanında lisansüstü eğitim verilmektedir. Bunlardan birinde (Atatürk Üniversitesi) yalnızca yüksek lisans eğitimi verilirken diğer dört bölümde hem yüksek lisans hem de doktora eğitimi verilmektedir. Bu bölümler Türkiye'de kurulan ilk Bilgi ve Belge Yönetimi bölümleridir.

\section{Tablo 3}

Öğretim elemanı sayıları

\begin{tabular}{lrrrrrr}
\hline Bölümler & Prof. Dr. & Doç. Dr. & $\begin{array}{l}\text { Dr. Öğr. } \\
\text { Üyesi }\end{array}$ & $\begin{array}{l}\text { Öğretim } \\
\text { Görevlisi }\end{array}$ & $\begin{array}{l}\text { Araştırma } \\
\text { Görevlisi }\end{array}$ & Toplam \\
\hline Ankara Üniversitesi & & 1 & - & 1 & 4 & 15 \\
Atatürk Üniversitesi & 1 & - & 4 & - & 2 & 7 \\
Çankırı Karatekin Üniversitesi & 2 & 1 & 3 & - & 4 & 10 \\
Hacettepe Üniversitesi & 6 & 2 & 4 & 4 & 4 & 20 \\
İstanbul Üniversitesi & 8 & 1 & 3 & 1 & 5 & 18 \\
İstanbul Medeniyet Üniversitesi & 1 & 1 & 3 & - & 2 & 7 \\
Kastamonu Üniversitesi & 1 & - & 3 & - & 2 & 6 \\
Marmara Üniversitesi & 4 & 3 & 4 & - & 3 & 14 \\
Osmaniye Korkut Ata Üniversitesi & - & - & 3 & - & 1 & 4 \\
Yıldırım Beyazıt Üniversitesi & - & - & 5 & - & 6 & 11 \\
\hline
\end{tabular}

Tablo 3'te Bilgi ve Belge Yönetimi bölümlerinde bulunan öğretim elemanı sayıları yer almaktadır. Öğretim elemanı sayısı en fazla olan üniversite Hacettepe Üniversitesi (20)'dir. Bunu 18 öğretim elemanı ile İstanbul Üniversitesi takip etmektedir. En az öğretim elemanı ise Osmaniye Korkut Ata Üniversitesi'nde (4) yer almaktadır. Toplam öğretim elemanı sayılarında çok farklılık olduğu görülmektedir. Genel olarak yeni açılan bölümlerde daha az öğretim elemanı bulunduğu görülse de Atatürk Üniversitesi’nde daha sonradan açılan Çankırı Karatekin ve Yıldırım Beyazıt üniversitelerinden daha az öğretim elemanı bulunmaktadır.

\section{Düşünce Özgürlüğü ile İlgili Derslere Yönelik Bulgular}

Çalışmanın bu bölümünde düşünce özgürlüğü ile ilgili derslere yönelik olarak bölümlerin Bologna bilgi paketlerinden elde edilen bulgulara yer verilmiştir. Bologna bilgi paketlerinden derslerin isimleri, kaçıncı sınıfta verildikleri, amaçları, içerikleri, öğretim yöntem ve teknikleri, öğrencilerin kazanımları gibi bilgilere erişilmiştir. 
Türkiye'deki Bilgi ve Belge Yönetimi Bölümleri Ders Programlarının Düşünce Özgürlüğü Eğitimi Açısından

Değerlendirmesi

Evaluation of the Syllabi of Information and Records Management Departments in Turkey in Terms of Intellectual Freedom Education

\section{Tablo 4}

Lisans programlarında düşünce özgürlüğ̈̈ ile ilgili içerik bulunan dersler

\begin{tabular}{|c|c|c|c|c|c|}
\hline Bölümler & Dersin $\mathrm{Ad}_{1}$ & Zorunlu/Seçmeli & AKTS & Kredi & Sinif \\
\hline Ankara Üniversitesi & Meslek Etiği & Zorunlu & 6 & 2 & 4. sinif \\
\hline Atatürk Üniversitesi & Meslek Etiği & Seçmeli & 4 & 2 & 4. sinif \\
\hline Çankırı Karatekin Üniversitesi & $\begin{array}{l}\text { Mesleki Etik ve Bilgi } \\
\text { Merkezleri }\end{array}$ & Zorunlu & 4 & 2 & 4. sinif \\
\hline Hacettepe Üniversitesi & Meslek Etiği & Zorunlu & 6 & 3 & 4. $\sin 1 f$ \\
\hline İstanbul Üniversitesi & Mesleki Etik & Zorunlu & 3 & 2 & 4. sinif \\
\hline İstanbul Medeniyet Üniversitesi & Mesleki Gelişim ve Etik & Zorunlu & 5 & 2 & 4. sinif \\
\hline Kastamonu Üniversitesi & Mesleki Etik & Zorunlu & 4 & 3 & 4. sinif \\
\hline Marmara Üniversitesi & - & - & - & - & - \\
\hline $\begin{array}{l}\text { Osmaniye Korkut Ata } \\
\text { Üniversitesi }\end{array}$ & Meslek Etiği & Zorunlu & 4 & 3 & 2. $\sin 1 f$ \\
\hline Yıldırım Beyazıt Üniversitesi & $\begin{array}{l}\text { Toplumsal İletişim ve } \\
\text { Mesleki Etik }\end{array}$ & Zorunlu & 4 & 3 & 1. $\sin 1 f$ \\
\hline
\end{tabular}

Not. AKTS: Avrupa Kredi Transfer Sistemi

Araştırma kapsamında 10 bölümün tüm dersleri Bologna Bilgi Paketleri üzerinden incelenmiş olup; içerik, amaç ve kazanımlarında düşünce özgürlüğü, telif hakları, sansür gibi kavramlar geçen dersler belirlenmiştir. Tablo 4'te de görüldüğü gibi lisans programlarının \%90'ında düşünce özgürlüğü konusu ile ilişkili olarak etik dersleri bulunmaktadır. Bu dersin adı bölümlere göre değişiklikler göstermektedir. Marmara Üniversitesi'nin Bologna bilgi paketinde düşünce özgürlüğü konusunun işlendiği bir ders bulunamamıştır. Bölümlerde Meslek Etiği (4), Mesleki Etik (2), Mesleki Etik ve Bilgi Merkezleri (1), Mesleki Gelişim ve Etik (1), Toplumsal İletişim ve Mesleki Etik (1) isimleriyle verilen derslerin içeriklerinde düşünce özgürlüğü konusu yer almaktadır. 8 Bölümde bu ders zorunlu ders olarak, Atatürk Üniversitesi'nde seçmeli ders olarak verilmektedir. Yıldırım Beyazıt Üniversitesi'nde 1. Sınıfta, Osmaniye Korkut Ata Üniversitesi'nde 2. sınıfta verilen ders, diğer bölümlerde 4. sinıfta verilmektedir. Derslerin AKTS'sinin Ankara Üniversitesi ve Hacettepe Üniversitesi'nde en yüksek (6) olduğu görülmektedir. En düşük AKTS (3) ise İstanbul Üniversitesi'ndedir. Derslerin tüm üniversitelerde 2 ve 3 kredi olarak verildiği görülmektedir. AKTS ders için öğrencinin iş yükünü gösteren bir değer olduğundan AKTS'nin yüksek olması bölümün o derse daha fazla ağırlık verdiğinin göstergesidir.

\section{Tablo 5}

Lisansüstü programlarında düşünce özgürlüğü ile ilgili içerik bulunan dersler

\begin{tabular}{lllrcc}
\hline Bölümler & Dersin Adı & Zorunlu/Seçmeli & AKTS & Kredi & $\begin{array}{c}\text { Yüksek } \\
\text { lisans/Doktora }\end{array}$ \\
\hline Ankara Üniversitesi & Etik sorunlar & Seçmeli & 10 & 3 & Doktora \\
Atatürk Üniversitesi & - & - & - & - & - \\
Hacettepe Üniversitesi & Düşünce özgürlüğü & Seçmeli & 10 & 3 & Doktora \\
& ve Bilgi hizmetleri & & & & - \\
İstanbul Üniversitesi & - & - & - & - & - \\
Marmara Üniversitesi & - & - & - & - & - \\
\hline
\end{tabular}


Lisansüstü programların \%50'sinde düşünce özgürlüğü ile ilişkili adları farklı görünen ders bulunmaktadır. Bu derslerin ikisi de doktora düzeyindedir (Ankara Üniversitesi ve Hacettepe Üniversitesi). Dersler seçmeli statüdedir. Ankara Üniversitesi’nde etik dersinin içinde düşünce özgürlüğü konusuna değinilmekte, Hacettepe Üniversitesi'nde ise düşünce özgürlüğü bağımsız bir ders olarak verilmektedir (Düşünce özgürlüğü ve bilgi hizmetleri).

\section{Tablo 6}

Programlarda yer alan düşünce özgürlüğ̈̈ ile ilgili derslerin amaçları

\begin{tabular}{|c|c|c|}
\hline Amaç & Bölümler (Lisans) & $\begin{array}{l}\text { Bölümler } \\
\text { (Lisansüstü) }\end{array}$ \\
\hline Mesleki etik ilkelerini öğretmek & $\begin{array}{l}\text { Ankara Üniversitesi } \\
\text { Çankırı Karatekin Üniversitesi } \\
\text { Hacettepe Üniversitesi } \\
\text { İstanbul Medeniyet Üniversitesi } \\
\text { Osmaniye Korkut Ata Üniversitesi }\end{array}$ & - \\
\hline $\begin{array}{l}\text { Mesleki etik, düşünce özgürlüğü, telif } \\
\text { hakları, sansür gibi kavramları öğretmek }\end{array}$ & $\begin{array}{l}\text { Atatürk Üniversitesi } \\
\text { Hacettepe Üniversitesi } \\
\text { İstanbul Medeniyet Üniversitesi } \\
\text { Osmaniye Korkut Ata Üniversitesi } \\
\text { Yıldırım Beyazıt Üniversitesi }\end{array}$ & $\begin{array}{l}\text { Ankara } \\
\text { Üniversitesi }\end{array}$ \\
\hline $\begin{array}{l}\text { Bilim ve bilişim etiği hakkında } \\
\text { bilgilendirmek }\end{array}$ & İstanbul Üniversitesi & \\
\hline Meslek bilinci geliştirmek & Ankara Üniversitesi & \\
\hline Etik sorunları tartışmak & İstanbul Üniversitesi & $\begin{array}{l}\text { Ankara } \\
\text { Üniversitesi }\end{array}$ \\
\hline $\begin{array}{l}\text { Mesleki etik ile ilgili farkındalık } \\
\text { oluşturmak }\end{array}$ & Kastamonu Üniversitesi & \\
\hline $\begin{array}{l}\text { Düşünce özgürlüğüne ilişkin kavram ve } \\
\text { olguları öğretmek. }\end{array}$ & - & $\begin{array}{l}\text { Hacettepe } \\
\text { Üniversitesi }\end{array}$ \\
\hline
\end{tabular}

Tablo 6'da düşünce özgürlüğü ile ilişkili derslerin Bologna bilgi paketlerinde yer alan amaçları tek biçim haline getirilerek gösterilmiştir. Derslerin genel olarak öğrencilere mesleğin etik ilkelerini, değer yargılarını, meslek bilincini öğretmek, mesleki sorumlulukları kazandırmak; öğrencileri bilgi hizmetlerinde karşılaşılan etik ile ilgili sorunlarla tanıştırmak gibi amaçları bulunmaktadır. Lisans programlarında etik dersi bulunan bölümlerin \%55'inde düşünce özgürlüğü kavramını öğretmeye yönelik bir amaç olsa da düşünce özgürlüğü ile ilgili farkındalık oluşturmak hiçbir dersin amacında geçmemektedir. Lisansüstü programlara bakıldığında ise Ankara Üniversitesi'nde etik dersi kapsamında düşünce özgürlüğü kavramını öğretmeye yönelik bir amaç bulunduğu, Hacettepe Üniversitesi doktora programında yer alan "Düşünce Özgürlüğü ve Bilgi Hizmetleri” dersinin temel amacının düşünce özgürlüğüne yönelik kavramların öğretilmesi olduğu görülmektedir. Mesleki etik dersleri ya da bağımsız olarak var olan düşünce özgürlüğü derslerinde düşünce özgürlüğü eğitimine ilişkin amaçlar bölümlere göre farklı ifadelerle ve kavramlarla açıklanmıştır. 
Türkiye'deki Bilgi ve Belge Yönetimi Bölümleri Ders Programlarının Düşünce Özgürlüğü Eğitimi Açısından

Değerlendirmesi

Evaluation of the Syllabi of Information and Records Management Departments in Turkey in Terms of Intellectual Freedom Education

Tablo 7

Programlarda yer alan düşünce özgürlüğü ile ilgili derslerin içeriği

\begin{tabular}{|c|c|c|}
\hline İçerik & Bölümler (Lisans) & $\begin{array}{l}\text { Bölümler } \\
\text { (Lisansüstü) }\end{array}$ \\
\hline Meslek etiği & $\begin{array}{l}\text { Ankara Üniversitesi } \\
\text { Atatürk Üniversitesi } \\
\text { Çankırı Karatekin Üniversitesi } \\
\text { Hacettepe Üniversitesi } \\
\text { İstanbul Üniversitesi } \\
\text { İstanbul Medeniyet Üniversitesi } \\
\text { Kastamonu Üniversitesi } \\
\text { Yıldırım Beyazıt Üniversitesi }\end{array}$ & $\begin{array}{l}\text { Ankara } \\
\text { Üniversitesi }\end{array}$ \\
\hline Mesleki etik ilkeler & $\begin{array}{l}\text { Ankara Üniversitesi } \\
\text { Atatürk Üniversitesi } \\
\text { Çankırı Karatekin Üniversitesi } \\
\text { İstanbul Medeniyet Üniversitesi } \\
\text { Kastamonu Üniversitesi } \\
\text { Osmaniye Korkut Ata Üniversitesi }\end{array}$ & $\begin{array}{l}\text { Ankara } \\
\text { Üniversitesi }\end{array}$ \\
\hline ALA, IFLA, TKD bildirgeleri & $\begin{array}{l}\text { Atatürk Üniversitesi } \\
\text { Çankırı Karatekin Üniversitesi } \\
\text { Hacettepe Üniversitesi } \\
\text { İstanbul Medeniyet Üniversitesi }\end{array}$ & - \\
\hline Etik sorunlar & $\begin{array}{l}\text { İstanbul Medeniyet Üniversitesi } \\
\text { Kastamonu Üniversitesi }\end{array}$ & $\begin{array}{l}\text { Ankara } \\
\text { Üniversitesi }\end{array}$ \\
\hline Durum çalışmaları & $\begin{array}{l}\text { Atatürk Üniversitesi } \\
\text { Hacettepe Üniversitesi } \\
\text { Kastamonu Üniversitesi }\end{array}$ & - \\
\hline Düşünce özgürlüğü, sansür, telif hakları & $\begin{array}{l}\text { Atatürk Üniversitesi } \\
\text { Çankırı Karatekin Üniversitesi } \\
\text { Hacettepe Üniversitesi } \\
\text { İstanbul Medeniyet Üniversitesi } \\
\text { Kastamonu Üniversitesi } \\
\text { Yıldırım Beyazıt Üniversitesi }\end{array}$ & $\begin{array}{l}\text { Ankara } \\
\text { Üniversitesi } \\
\text { Hacettepe } \\
\text { Üniversitesi }\end{array}$ \\
\hline Bilgi erişim özgürlüğü & İstanbul Medeniyet Üniversitesi & $\begin{array}{l}\text { Hacettepe } \\
\text { Üniversitesi }\end{array}$ \\
\hline Bilgi edinme hakk1 & Y1ldırım Beyazıt Üniversitesi & $\begin{array}{l}\text { Hacettepe } \\
\text { Üniversitesi }\end{array}$ \\
\hline Fikri mülkiyet hakları & - & $\begin{array}{l}\text { Hacettepe } \\
\text { Üniversitesi }\end{array}$ \\
\hline
\end{tabular}

Düşünce özgürlüğü ile ilgili lisans ve lisansüstü düzeylerde verilen derslerin Bologna Bilgi Paketleri'nde yer alan içerikleri düzenlenerek Tablo 7'de sunulmuştur. Ders içerikleri genellikle meslek etiği, mesleki etik ilkeler, ALA, IFLA ve TKD'nin bildirgeleri, etik sorunlar gibi konuları kapsamaktadır. Lisans programı etik derslerinin \%67'sinde düşünce özgürlügü, sansür, telif hakları gibi konular ders içeriklerinde yer almaktadır. Düşünce özgürlüğü ile yakından ilişkili olan bilgi erişim özgürlüğü, bilgi edinme hakkı, fikri mülkiyet hakları gibi konulara ise lisans programlarında yalnızca İstanbul Medeniyet ve Yıldırım Beyazıt üniversitelerinde değinilmektedir. Lisansüstü düzeyde düşünce özgürlüğü, sansür, telif hakları 
konuları Hacettepe ve Ankara üniversitelerinin; bilgi erişim özgürlüğü, bilgi edinme hakk1, fikri mülkiyet hakları konuları sadece Hacettepe Üniversitesi'nin ders içeriklerinde yer almaktadır. İlgili derslerin düşünce özgürlüğüne ilişkin içeriklerinde öncelik ve ağırlık verilen kavram ve olgular bölümlere göre değişebilmektedir.

\section{Tablo 8}

Programlarda yer alan düşünce özgürlüğü ile ilgili derslerde kullanılan ögrretim yöntem ve teknikleri

\begin{tabular}{|c|c|c|c|c|c|c|}
\hline \multirow[t]{2}{*}{ Bölümler } & \multirow[t]{2}{*}{ Dersin Ad 1} & \multicolumn{5}{|c|}{ Yöntem ve teknikler } \\
\hline & & Anlatım & $\begin{array}{l}\text { Soru- } \\
\text { yanit }\end{array}$ & Tartışma & Uygulama & Grup çalışması \\
\hline Ankara & Meslek Etiği & $\mathrm{X}$ & $\mathrm{X}$ & $\mathrm{X}$ & - & - \\
\hline Üniversitesi & Etik Sorunlar & $\mathrm{X}$ & $\mathrm{X}$ & $\mathrm{X}$ & - & - \\
\hline $\begin{array}{l}\text { Atatürk } \\
\text { Üniversitesi }\end{array}$ & Meslek Etiği & $\mathrm{X}$ & - & - & - & - \\
\hline $\begin{array}{l}\text { Çankırı Karatekin } \\
\text { Üniversitesi }\end{array}$ & $\begin{array}{l}\text { Mesleki Etik } \\
\text { ve Bilgi } \\
\text { Merkezleri }\end{array}$ & - & - & - & - & - \\
\hline $\begin{array}{l}\text { Hacettepe } \\
\text { Üniversitesi }\end{array}$ & $\begin{array}{l}\text { Meslek Etiği } \\
\text { Düşünce } \\
\text { Özgürlüğü ve } \\
\text { Bilgi } \\
\text { Hizmetleri }\end{array}$ & $\begin{array}{l}X \\
X\end{array}$ & - & $\begin{array}{l}X \\
X\end{array}$ & - & $\begin{array}{l}- \\
-\end{array}$ \\
\hline $\begin{array}{l}\text { İstanbul } \\
\text { Üniversitesi }\end{array}$ & Mesleki Etik & $\mathrm{X}$ & $\mathrm{X}$ & $\mathrm{X}$ & - & - \\
\hline $\begin{array}{l}\text { İstanbul } \\
\text { Medeniyet } \\
\text { Üniversitesi }\end{array}$ & $\begin{array}{l}\text { Mesleki } \\
\text { Gelişim ve } \\
\text { Etik }\end{array}$ & - & - & - & - & - \\
\hline $\begin{array}{l}\text { Kastamonu } \\
\text { Üniversitesi }\end{array}$ & Mesleki Etik & - & - & - & - & - \\
\hline $\begin{array}{l}\text { Osmaniye Korkut } \\
\text { Ata Üniversitesi }\end{array}$ & Meslek Etiği & - & - & - & - & - \\
\hline $\begin{array}{l}\text { Yıldırım Beyazıt } \\
\text { Üniversitesi }\end{array}$ & $\begin{array}{l}\text { Toplum ve } \\
\text { Mesleki Etik }\end{array}$ & $\mathrm{X}$ & - & $\mathrm{X}$ & - & - \\
\hline
\end{tabular}

Tablo 8'de Bologna bilgi paketlerine göre derslerin öğretim yöntem ve teknikleri gösterilmiştir. Derslerde uygulama ve grup çalışması yöntemlerinin kullanılmadığı görülmektedir. Ankara ve İstanbul üniversitelerinde anlatım, soru yanıt ve tartışma yöntemlerinin üçü de kullanılmaktadır. Hacettepe ve Yıldırım Beyazıt üniversitelerinde anlatım ve tartışma yöntemleri, Atatürk Üniversitesi’nde ise sadece anlatım teknikleri kullanılmaktadır. Diğer üniversitelerin Bologna bilgi paketlerinde derslerin öğretim yöntem ve teknikleri ile ilgili bilgi bulunmamaktadır. Öğretim üyeleri ile yapılan görüşmelerde konu ile ilgili bilgi alınmış, çalışmanın ilerleyen bölümlerinde yer verilmiştir. 
Türkiye'deki Bilgi ve Belge Yönetimi Bölümleri Ders Programlarının Düşünce Özgürlüğü Eğitimi Açısından Değerlendirmesi

Evaluation of the Syllabi of Information and Records Management Departments in Turkey in Terms of Intellectual Freedom Education

\section{Tablo 9}

Programlarda yer alan düşünce özgürlüğü ile ilgili derslerde beklenen kazanımlar

\begin{tabular}{lll}
\hline Kazanımlar & Bölümler (Lisans) & Bölümler (Lisansüstü) \\
\hline Etik ve meslek etiği ile ilgili kavramları & Ankara Üniversitesi & - \\
açıklamak ve tartışmak & Hacettepe Üniversitesi & \\
& İstanbul Medeniyet Üniversitesi & \\
& Kastamonu Üniversitesi & Ankara Üniversitesi \\
& Osmaniye Korkut Ata Üniversitesi & \\
Mesleki etik ilkeleri bilmek & Yıldırım Beyazıt Üniversitesi & - \\
Mesleki bilinç kazanmak & Ankara Üniversitesi & - \\
Etik ve etik dışı davranışları & İstanbul Medeniyet Üniversitesi & Ankara Üniversitesi \\
değerlendirmek & Ankara Üniversitesi \\
Etik sorunlara çözüm önerileri & Çankırı Karatekin Üniversitesi & \\
geliştirmek & & Ankara Üniversitesi \\
Düşünce özgürlüğü, sansür, telif hakları & Ankara Üniversitesi & Hacettepe Üniversitesi \\
gibi konuları tartışmak ve açıklamak & İstanbul Medeniyet Üniversitesi & \\
\cline { 2 - 3 } & Yıldırım Beyazıt Üniversitesi & \\
\hline
\end{tabular}

Tablo 9'da derslerin Bologna Bilgi Paketleri'nde yer alan kazanımları gösterilmiştir. Lisans derslerinin çoğunda etik ile ilgili kavramları bilmek, açıklamak, tartışmak kazanımlar arasında yer almaktadır. Bunun dışında mesleki etik ilkeleri bilmek, etik davranışlarını ve değerleri anlamak, mesleki bilinç geliştirmek gibi kazanımlar bulunmaktadır. Özelde düşünce özgürlüğüne yönelik kazanım bölümlerin çoğunda belirtilmemiştir. Lisans programlarının \%33'ünde düşünce özgürlüğü, sansür, telif hakları gibi konuları tartışmak ve değerlendirmek kazanımlar arasında yer almaktadır. Lisansüstü düzeyde ise iki doktora programında bu kazanımlara yer verilmiştir. İçerik açısından yakın görünmekle birlikte, ilgili dersler bağlamında öne çıkarılan kazanımlar açısından bölümler arasında farklı ifadeler rastlanmıştır.

\section{Öğretim Üyeleriyle Yapılan Görüşmelerden Elde Edilen Bulgular}

Bu bölümde Bilgi ve Belge Yönetimi bölümlerindeki düşünce özgürlüğü ile ilgili konuların işlendiği etik derslerinin sorumlusu olan öğretim üyeleri ile gerçekleştirilen görüşmeler sonucunda elde edilen bulgular ve değerlendirmeler yer almaktadır. Öğretim üyelerine derslerle ilgili aşağıdaki sorular sorulmuştur:

1. İlgili dersinizde düşünce özgürlüğü konusuna ne kadar ve hangi bağlamda değiniyorsunuz? 
2. Sizce, geleceğin kütüphanecileri olacak BBY bölümü öğrencilerinde düşünce özgürlüğüne yönelik farkındalık oluşturmak önemli midir ve sizin dersinizde bu farkındalık yeterince oluşuyor mu?

3. Düşünce özgürlüğü konusunda herhangi bir ödev veriyor musunuz ve sınavda konu ile ilgili soru soruyor musunuz?

4. Düşünce özgürlüğü ile ilgili bağımsız bir ders olması gerektiğini düşünüyor musunuz?

Görüşmeler sonucunda düşünce özgürlüğü konusuna tüm öğretim üyelerinin önem verdiği görülmüştür. Üniversiteden üniversiteye farklı yaklaşım ve öğretim yöntemleri tercih edilse de düşünce özgürlüğü etik derslerinde en çok üstüne düşülen konulardandır. Çankırı Karatekin Üniversitesi'nde 14 haftalık dersin 2 haftasında yalnızca düşünce özgürlüğü konusunun anlatıldığ 1 belirtilmiştir. Hacettepe Üniversitesi’nde ise düşünce özgürlüğünü derste işlemenin yanı sıra Ankara Ulucanlar Cezaevine gezi düzenleyerek, konunun düşüncesi nedeniyle ceza almış kişiler bağlamında değerlendirilmesi sağlanmaya çalışılmaktadır. Öğretim üyeleri mesleki etik derslerinin dişında diğer derslerinde de düşünce özgürlüğüne değinebilmektedirler. Düşünce özgürlüğüne derslerde genellikle danışma hizmetleri, derme geliştirme, sınıflama, bilgi erişimi gibi konular anlatılırken değinilmektedir.

Öğretim üyelerine BBY öğrencilerinde düşünce özgürlüğüne yönelik farkındalık oluşturma konusunu önemli bulup bulmadıkları sorulmuştur. Tüm öğretim üyeleri bu konunun önemli olduğunu düşündüklerini belirtmiştir. Öğretim üyeleri ilgili dersler sonucunda öğrencilerde genellikle farkındalık oluştuğunu gözlemlediklerini ve düşünce özgürlüğü konusunun siyasi çerçevede değil mesleki boyutuyla öğretildiğini söylemiştir.

Öğretim üyelerinin derslerde ödev vermek ile ilgili de yaklaşımlarının farklı olduğu görülmektedir. Çoğunlukla etik dersleri kapsamında düşünce özgürlüğü ile ilgili ödev verilmemekte ancak sınavda bu konuda sorular sorulmaktadır. Çankırı Karatekin Üniversitesi’nde düşünce özgürlüğü ile ilgili iki ödev verildiği belirtilmiştir. Bu ödevlerden birinde düşünce özgürlüğünün alanımız açısından önemine yönelik bir rapor, diğerinde ise düşünce özgürlüğü ve bilgi hizmetleri ilişkisine yönelik dünyadaki mevcut durumun analizine ilişkin bir rapor istenmektedir. İstanbul Üniversitesi'nde düşünce özgürlüğü ile ilgili ödev verilmemekte ancak öğrencilerin her derste özgür bir şekilde düşüncelerini paylaşmalarına ve farklı fikirler bağlamında tartışmalarına ortam hazırlanarak öğrencilerin düşünce özgürlüğü bilincini geliştirmeye katkı sağlanmaktadır.

Öğretim üyelerinin çoğu düşünce özgürlüğü ile ilgili bağımsız bir ders olmasının faydalı olacağını, bağımsız ders olmasa da mutlaka etik derslerinin içeriğinde ayrıntılı bir biçimde yer alması gerektiğini düşünmektedirler. Osmaniye Korkut Ata Üniversitesi öğretim üyesine göre ders sorumlusunun bu alana hâkim biri olması gerekmektedir. Hacettepe Üniversitesi öğretim üyesine göre, düşünce özgürlügüne yönelik olarak yüksek lisans ve doktora düzeyinde kesinlikle bağımsız, lisans düzeyinde de seçmeli bir ders olmalıdır. Kastamonu Üniversitesi öğretim üyesine göre ise düşünce özgürlüğünün bağımsız bir ders olmasına gerek yoktur ancak birinci sınıftan dördüncü sınıfa kadar birçok derste anlatılmalıdır.

\section{Tartışma}

Türkiye'de 13 üniversitede Bilgi ve Belge Yönetimi Bölümü bulunmaktadır. Bunlardan öğrenci alan 10 bölüm araştırma kapsamına alınmıştır. Son 3 yıldır 10 Bölüme ortalama 600 civarında 
Türkiye'deki Bilgi ve Belge Yönetimi Bölümleri Ders Programlarının Düşünce Özgürlüğü Eğitimi Açısından Değerlendirmesi

Evaluation of the Syllabi of Information and Records Management Departments in Turkey in Terms of Intellectual Freedom Education

öğrenci alınmaktadır. Bölümler arasında öğrenci alım sayıları açısından farklılıklar bulunmaktadır. Bölümlerin yarısında lisansüstü eğitim verilmektedir. Bölümlerin öğretim elemanı sayılarına bakıldığında ise bölümler arasında ciddi bir farklılık olduğu görülmektedir. Örneğin Hacettepe Üniversitesi’nde Osmaniye Korkut Ata Üniversitesi'nden beş kat fazla öğretim elemanı bulunmaktadır. Ancak öğrenci alımlarında aynı oranda bir farklılık olmadığı dikkat çekmektedir. Osmaniye Korkut Ata Üniversitesi'nin kendisinden dört kat fazla öğretim elemanına sahip olan Ankara Üniversitesi’nden daha fazla öğrencisi bulunmaktadır. Bu durum kuşkusuz, verilen eğitimin niteliğini de etkileyebilmektedir. Düşünce özgürlüğüne yönelik verilecek olan derslerin sayısının ve niteliğinin artırılması için öncelikle öğretim elemanıöğrenci sayısı dengesinin kurulması gerektiği düşünülmektedir.

Bölümlerde lisans programlarında düşünce özgürlüğü ile ilgili zorunlu ya da seçmeli statüde bağımsız bir ders bulunmamaktadır. Düşünce özgürlüğü konuları genellikle mesleki etik dersleri içinde işlenmektedir. $\mathrm{Bu}$ durum şaşırtıcı bir sonuç olmamıştır. Çalışmanın kavramsal arka planında da bahsedildiği üzere Türk Kütüphaneciler Derneği'nin hazırlamış olduğu Mesleki Etik İlkeleri'nde de yine derneğin hazırladığı Düşünce Özgürlüğü Bildirgesi'ne uyulması gerektiği vurgulanmıştır (Türk Kütüphaneciler Derneği, 2010). Ayrıca Asato'nun $(2014$, s. 6) çalışması da düşünce özgürlüğünün çoğunlukla koleksiyon yönetimi veya etik dersleri içinde anlatıldığını göstermektedir. Lisansüstü eğitim veren Ankara Üniversitesi'nde düşünce özgürlüğü ile ilişkili olarak yine etik dersi bulunmakta, Hacettepe Üniversitesi doktora programında "Düşünce Özgürlüğü ve Bilgi Hizmetleri" adında bağımsız bir ders yer almaktadır.

Lisans programlarında bulunan mesleki etik dersleri çoğunlukla zorunlu, 4 AKTS ve 4. Sınıf dersi olarak verilmektedir. Etik derslerinin 4. sınıfta verilmesi düşünce özgürlüğü bağlamında da uygun görülmektedir. Çünkü henüz teknik işlemlerin ve kullanıcı hizmetlerinin ne olduğunu doğal olarak öğrenmemiş öğrencilere teknik hizmetlerde yapılan sansür uygulamalarının veya kullanıcı hizmetlerini bilmeyen öğrenciye kullanıcının bilgi edinme hakkı, kişisel mahremiyet hakkı gibi konuların anlatılması oldukça zordur.

Lisans programlarının yarısı kadarı etik derslerinde düşünce özgürlüğü, telif hakları, sansür gibi kavramları öğretmeyi amaç edinmektedir. Lisansüstü programlarda ise Ankara Üniversitesi etik dersi kapsamında düşünce özgürlüğü, telif hakları ve sansür kavramlarını öğretmeyi amaç edinmektedir. Düşünce özgürlüğü ile ilgili farkındalık oluşturmak hiçbir bölümde derslerin amaçları arasında yer almamaktadır. Spesifik olarak düşünce özgürlüğüne ilişkin kavram ve olguları öğretmek ise Hacettepe Üniversitesi doktora programında yer alan dersin temel amacıdır. Çankırı Karatekin, Kastamonu ve İstanbul üniversitelerinde derslerde düşünce özgürlüğüne yönelik bir amaç bulunmamaktadır. Ancak bu bulguların yalnızca Bologna Bilgi Paketlerinden elde edildiği ve bunların güncellenmemiş olma ihtimali unutulmamalıdır. Nitekim öğretim üyeleriyle yapılan görüş̧melerde tüm öğretim üyelerinin düşünce özgürlüğü konusunu öğretmeyi önemsedikleri ortaya çımaktadır.

Bölümlerin çoğunda mesleki etik derslerinin içeriğinde düşünce özgürlüğü, sansür ve telif hakları gibi konuların yer aldığı görülmüştür. Osmaniye Korkut Ata ve İstanbul 
üniversitelerinin Bologna Bilgi Paketlerindeki ders içeriklerinde bu konulara yer verilmemiştir. Düşünce özgürlüğü ile yakından ilişkili olan bilgi erişim özgürlüğü, bilgi edinme hakkı ve fikri mülkiyet hakları gibi konuların lisans programlarında İstanbul Medeniyet ve Yıldırım Beyazıt üniversitelerinde, lisansüstü programlarda ise Hacettepe Üniversitesinde ders içeriğine dâhil edildiği görülmektedir. Atatürk, Çankırı Karatekin, Hacettepe ve İstanbul Medeniyet üniversitelerinde ders içeriklerinde ALA, IFLA ve TKD bildirgeleri de yer almaktadır. Shuman'ın (1977, s. 104) ve Asato'nun (2014, s. 5) çalışmaları Amerika'da ve Japonya'da da düşünce özgürlüğü ile ilişkili derslerde en fazla ALA bildirgeleri, otosansür, seçim politikası, istisna durumlar, eşitlik, gizlilik gibi konuların ele alındığını göstermektedir. Türkiye'deki etik dersleri veya bağımsız düşünce özgürlüğü derslerinde de otosansür, kişisel mahremiyet, materyal seçiminde sansür gibi konuların işlenmesi gerektiği düşünülmektedir.

Mesleki etik derslerinin yöntem ve teknikleri çoğunlukla anlatım ve tartışma şeklinde belirlenmiştir. Bazı bölümlerde soru-yanıt ve durum çalışması tekniği de var olmakla birlikte, uygulama ve grup çalışması hiçbir dersin yöntem ve teknikleri arasında yer almamaktadır. $\mathrm{Bu}$ bilgiler Bologna Bilgi Paketlerinde güncellenmemiş olabilir ancak Kızılkan’ın (1994, s. 56) çalışmasına göre de kütüphanecilik bölümü öğretim üyeleri bu derslerin en çok tartışma yöntemiyle işlenmesi, bunu anlatım yönteminin takip etmesi gerektiğini düşünmektedir. Amerika'da ise anlatım ve tartışmanın yanı sıra okuma ve durum çalışması yöntemlerinin de kullanıldığ1 görülmektedir (Shuman, 1977, s. 105).

Derslerin kazanımlarında lisans programlarında yalnızca Ankara, İstanbul Medeniyet ve Yıldırım Beyazıt üniversitelerinde, lisansüstü programlarda ise Ankara ve Hacettepe üniversitelerinde düşünce özgürlügü, sansür, telif hakları gibi konuları tartışmak ve açıklamak yer almaktadır. Bölümlerin programlarında yer alan ilgili derslerin kazanımlarında düşünce özgürlüğü ile ilgili ifadeler ve yer alma düzeyi bölümlere göre farklılıklar göstermektedir.

Mesleki etik derslerinin sorumlusu olan öğretim üyeleriyle yapılan görüşmeler sonucunda farklı öğretim yöntem ve yaklaşımları benimsense de tüm öğretim üyelerinin düşünce özgürlüğüne önem verdiği ortaya çıkmıştır. Etik derslerinde üstüne en çok düşülen konulardan olan düşünce özgürlüğü, öğretim üyelerinin diğer derslerinde de belirli oranda işlenmektedir. Görüşülen öğretim üyelerine göre dersler kapsamında öğrencilerde düşünce özgürlüğüne yönelik bir farkındalık oluşmaktadır. Öğretim üyelerinin çoğunluğu düşünce özgürlüğü ile ilgili olarak ödev vermese de sınavlarda mutlaka soru sormaktadır. Öğretim üyeleri tarafından genellikle düşünce özgürlüğünün bağımsız bir ders olması gerektiği düşünülmektedir. Kızılkan (1994, s. 56) yaklaşık otuz y1l önce yapmış olduğu çalışmasında Türkiye'deki kütüphanecilik bölümü öğretim üyelerinin tamamının düşünce özgürlüğü konusuna müfredatta yer verilmesi gerektiğini ancak çoğunluğunun bağımsız bir ders olarak verilmesine gerek olmadığını düşündüğünü ortaya çıkarmıştır. Aradan geçen süre zarfinda ders programlarında düşünce özgürlüğüne yönelik olarak çok fazla değişiklik olmadığı ancak öğretim üyelerinin bağımsız bir ders olmasına ilişkin düşüncelerinin değiştiği görülmektedir. Shuman'ın (1977, s. 106) çalışmasına göre düşünce özgürlüğünün Amerika'da bağımsız bir ders olarak verilmesinden çok müfredat boyunca derslerde yer alması gereken bir konu olduğu; Asato'nun (2014, s. 5) çalışmasına göre ise Japonya' da bağımsız bir derste işlenmesi gereken bir konu olduğu düşünülmektedir. $\mathrm{Bu}$ konu hakkında farklı görüş ve yaklaşımlar bulunmaktadır. 
Türkiye’deki Bilgi ve Belge Yönetimi Bölümleri Ders Programlarının Düşünce Özgürlüğü Eğitimi Açısından Değerlendirmesi

Evaluation of the Syllabi of Information and Records Management Departments in Turkey in Terms of Intellectual Freedom Education

Düşünce özgürlüğü konusuna yaklaşımları açısından eski ve yeni kurulan Bilgi ve Belge Yönetimi bölümleri arasında anlamlı bir farklılık da bulunmamaktadır. Eski bölümlerden olan Marmara Üniversitesi'nde konu ile ilişkili ders bulunmamakta, yeni açılan bölümlerde ise etik dersleri içinde anlatılmaktadır. Yine en eski bölümlerden olan İstanbul Üniversitesi'nin etik dersinde düşünce özgürlüğüne yönelik bir amaç bulunmamakta ancak yeni bölümlerden olan İstanbul Medeniyet, Osmaniye Korkut Ata ve Yıldırım Beyazıt üniversitelerinde bulunmaktadır. Derslerin içeriklerinde de İstanbul Üniversitesi'nde düşünce özgürlüğü ile ilişkili olgulara yer verilmemekte; Çankırı Karatekin, Kastamonu, Yıldırım Beyazıt ve İstanbul Medeniyet üniversitelerinde düşünce özgürlüğ̈̈, sansür, telif hakları, bilgi erişim hakkı gibi konular yer almaktadır.

\section{Sonuç ve Öneriler}

Toplumlarda düşünce özgürlüğü hakkı bireyler bilgiye eriştikçe artmaktadır. Bu bağlamda bilgi merkezlerinin bilgiyi din, dil, ırk, yaş, cinsiyet veya siyasi görüş ayrımı yapmadan herkese eşit koşullarda eriştirmesi düşünce özgürlüğünün gelişimi açısından son derece önemlidir. Bilgi merkezlerinde isteyerek veya istemeden uygulanan sansürün önüne geçilmesinde, bilgi profesyonellerinin yetiştirildiği Bilgi ve Belge Yönetimi bölümlerinde düşünce özgürlüğüne yönelik eğitim verilmesinin rolü büyüktür. Bu çalışmada Türkiye'deki Bilgi ve Belge Yönetimi bölümlerinin ders programlarında düşünce özgürlüğüne ne kadar ağırlık verildiği araştırılmıştır.

Bilgi ve belge yönetimi eğitimi, öğrencilere, bilginin elde edilmesi, düzenlenmesi ve gereksinim duyanlara sunulması süreçlerindeki işlem ve hizmetlerle ilgili bilimsel yöntemlerle bilgi ve mesleki becerilerin kazandırılmasını amaçlar. Düşünce özgürlüğ̈̈, burada sözü edilen tüm süreçlerde temel alınması gereken etik yaklaşım ve ilkeleri belirler. Bir başka deyişle, bilginin elde edilmesi, düzenlenmesi ve sunulması ancak düşünce özgürlüğü yaklaşımı temelinde yapıllırsa doğru yapılmış olur. Düşünce özgürlüğü konusunda bilinçli öğrenciler yetiştirmek bu alandaki bilimsel ve mesleki eğitimin zorunlu boyutları arasında yer alır ve bu nedenle de düşünce özgürlüğü eğitiminin yeterli/nitelikli biçimde verilmesi Bilgi ve Belge Yönetimi bölümlerinin en önemli sorumluluk noktalarından birisini oluşturur.

Genel sonuç olarak, gerek Bologna bilgi paketlerinde yer alan içerik incelemesi ve gerekse öğretim üyeleri ile yapılan görüşmelerden elde edilen verilere dayanarak, Türkiye'deki Bilgi ve Belge Yönetimi bölümlerinde düşünce özgürlüğü konusunda verilen eğitimin bölümlerin yaklaşımları ve politikalarına bağlı olarak bazı açılardan farklılıklar gösterdiği söylenebilir.

Çalışmanın sonuçları göz önüne alınarak aşağıdaki öneriler sunulmuştur:

- Düşünce özgürlüğü konusunun bilgi ve belge yönetimi bölümleri için önemi düşünülerek, lisans ve lisansüstü düzeylerde düşünce özgürlüğü ile ilgili seçmeli veya zorunlu statüde bağımsız bir ders açılması uygun görülmektedir.

- Düşünce özgürlüğüne yönelik olarak bağımsız bir ders açılırsa, dersin sorumlusu mutlaka konuya hâkim bir öğretim üyesi olmalıdır. 
- Düşünce özgürlüğü ile ilişkili olan meslek etiği derslerinin tüm bölümlerde zorunlu olması önemli görülmektedir.

- Düşünce özgürlügü ile ilgili bağımsız bir ders yoksa meslek etiği derslerinin temel amaçlarından birinin de düşünce özgürlüğüne yönelik farkındalık oluşturmak olması gerektiği düşünülmektedir.

- Tüm bölümlerde meslek etiği derslerinde düşünce özgürlügü, sansür, telif hakları, bilgi erişim özgürlüğü, bilgi edinme hakkı ve fikri mülkiyet hakları gibi konuların işlenmesinin önemli olduğu düşünülmektedir.

- Derslerin yöntem ve tekniklerinde anlatım ve tartışmanın yanı sıra grup çalışması ve durum çalışması yöntemlerinin de kullanımı yararlı olacaktır.

- Meslek etiği ders çıktılarında mesleki etik ilkeleri bilmek ve etik sorunlar ile baş edebilmek gibi kazanımların yanında, düşünce özgürlüğü ve ilişkili kavramlar hakkında bilinçlenmek gibi kazanımlarda yer almalıdır.

- Yalnızca düşünce özgürlüğü, meslek etiği gibi ders sorumlularının değil, geleceğin bilgi profesyonellerini yetiştiren tüm öğretim elemanlarının düşünce özgürlüğü, sansür, telif hakları gibi konuları bilmesi, konuya duyarlı olması ve önem vermesi beklenmektedir. Bu kapsamda öğretim elemanlarını yetiştiren doktora programlarında dersin verilmesi önem taşımaktadır.

- Bölümlerde düşünce özgürlüğü konusunda lisans, yüksek lisans ve doktora düzeyinde araştırmalar ve tezler yapılması teşvik edilmelidir.

- Bölümler bilgi hizmetleri çalışanlarına yönelik olarak düşünce özgürlüğü ile ilgili seminer, çalıştay, konferans gibi sürekli/hizmet içi eğitim etkinlikleri düzenlemelidir. $\mathrm{Bu}$ etkinliklerde mesleki sivil toplum kuruluşları ile de işbirliği yapmalıdır.

- Mezuniyet sonrası için düşünce özgürlüğü ile ilgili yaşanan sorunların tartışılabileceği platformlar oluşturmak, seminerler düzenlemek konusunda mesleki derneklerimize büyük bir rol düşmektedir.

Gelecek çalışmalarda bölümlerin tüm öğretim üyelerinin dersleri kapsamında düşünce özgürlüğü ve ilişkili konulara hangi bağlamlarda değindikleri araştırılabilir, böylece bölümlerde Bologna Bilgi Paketlerinde yer almasa da konuyu ele alan dersler saptanıp değerlendirilebilir. Ayrıca birinci sınıf ve dördüncü sınıf öğrencilerinin konuya ilişkin yaklaşımları karşılaştırılarak bölümlerin düşünce özgürlüğü eğitimi konusunda mevcut durumları belirlenebilir.

\section{Kaynakça}

Alaca, E. ve Y1lmaz, B. (2015). Halk kütüphaneciliğinde sansür ve düşünce özgürlüğü konusunda kullanıcı algısı üzerine bir araştırma. H. S. Keseroğlu, G. Demir, E. Bitri ve A. Güneş (Yay. Haz.), 1. Uluslararası Kütüphane ve Bilgibilim Felsefesi Sempozyumu, Etik: Kuram ve Uygulama, 3-5 Eylül 2014 içinde (ss. 87-102). İstanbul: Hiperlink. http://acikerisim.ybu.edu.tr:8080/handle/123456789/352 adresinden erişildi.

American Library Association. (2015). Intellectual Freedom Manual, Ninth Edition. https://www.alastore.ala.org/content/intellectual-freedom-manual-ninth-edition adresinden erişildi. 
Türkiye’deki Bilgi ve Belge Yönetimi Bölümleri Ders Programlarının Düşünce Özgürlüğü Eğitimi Açısından

Değerlendirmesi

Evaluation of the Syllabi of Information and Records Management Departments in Turkey in Terms of Intellectual Freedom Education

American Library Association. (2017). First Amendment and Censorship. http://www.ala.org/advocacy/intfreedom/censorship adresinden erişildi.

American Library Association. (2019). Library Bill of Rights. http://www.ala.org/advocacy/intfreedom/librarybill adresinden erişildi.

American Library Association. (2020). Intellectual Freedom and Censorship $Q \& A$. http://www.ala.org/advocacy/intfreedom/censorship/faq adresinden erişildi.

Asato, N. (2014). Intellectual freedom education in Japan and the United States: A comparative study. International Information \& Library Review, 46(1-2), 1-10. doi: 10.1080/10572317.2014.924776

Berninghausen, D. K. (1969). Teaching a commitment to intellectual freedom. Book selection and censorship in the sixties. E: Moon (Ed.). New York: RR Bowker. 385-394.

Canata, F. (2016). Düşünce özgürlüğü ve internet sansürü: İstanbul Üniversitesi Bilgi ve Belge Yönetimi Bölümü 4. sınıf öğrencileri üzerine betimsel bir araştırma. Türk Kütüphaneciliği, 30(4), 619-639. http://www.tk.org.tr/index.php/TK/article/view/2728 adresinden erişildi.

Cohen, L., Manion, L. ve Morrison, K. (2007). Research methods in education (6th ed.). New York: Routledge. https://gtu.ge/Agro-Lib/RESEARCH\%20METHOD\%20COHEN\%20ok.pdf adresinden erişildi.

Çakmak, T. ve Yılmaz, B. (2012). Türkiye'de kültürel bellek kurumlarındaki dijitalleştirme çalışmalarının düşünce özgürlüğü bağlamında değerlendirilmesi. Bilgi Dünyası, 13(2), 418-436. https://bd.org.tr/index.php/bd/article/view/149 adresinden erişildi.

Çelik, A. ve Tonta, Y. (1996). Düşünce özgürlüğü, bilgi edinme özgürlüğü ve bilgi hizmetleri. Bilgi Edinme Özgürlüğü içinde (1-13). Ed.Yaşar Tonta ve Ahmet Çelik. Ankara: Türk Kütüphaneciler Derneği. http://eprints.rclis.org/14748/ adresinden erişildi.

Ekici, S. ve Yılmaz, B. (2013). Hacettepe Üniversitesi İlköğretim Bölümü Öğrencilerinin düşünce özgürlüğüne ilişkin tutumları. Bilgi Dünyası, 14(1), 17-36. http://bilgidunyasi.xyz/index.php/bd/article/view/1_adresinden erişildi.

Fiske, M. (1959). Book selection and cencorship: A study of school and public libraries in California. Berkeley: University of California Press.

Gülle, M. T. (1997). Türkiye'de düşünce özgürlüğü sorunu ve halk kütüphanelerine yansımast. (Yayımlanmamış doktora tezi). Hacettepe Üniversitesi Sosyal Bilimler Enstitüsü, Ankara. http://bby.hacettepe.edu.tr/yayinlar/15.pdf adresinden erişildi.

IFLA (International Federation of Library Associations and Institutions). (2016). FAIFE Mission. https://www.ifla.org/faife/mission adresinden erişildi.

Indiana University. (2020). Library and Information Science Courses. https://soic.iupui.edu/lis/masterlibrary-science/courses/ adresinden erişildi.

Kızılkan, Z. (1988). Düşünce özgürlüğü ve kütüphanecilik. Türk Kütüphaneciliği, 2(4), 159-165. http://www.tk.org.tr/index.php/TK/article/view/1305 adresinden erişildi.

Kızılkan, Z. (1994). Düşünce özgürlüğ̈̈ ve Türkiye'deki kütüphanecilik eğitimi. (Yayımlanmamış yüksek lisans tezi). Hacettepe Üniversitesi Sosyal Bilimler Enstitüsü, Ankara. http://bby.hacettepe.edu.tr/yayinlar/35.pdf adresinden erişildi. 
Oltmann, S. M. (2017). Intellectual freedom in academic libraries: surveying deans about its significance. College \& Research Libraries, 78(6), 741-760. doi: 10.5860/crl.78.6.741

Özışı, M. E. (2019). Bilginin toplumsal iletişiminde düşünce özgürlüğü açısından kütüphanelerin rolü. (Yayımlanmamış yüksek lisans tezi). Ankara Üniversitesi Sosyal Bilimler Enstitüsü, Ankara. https://dspace.ankara.edu.tr/xmlui/handle/20.500.12575/69005 adresinden erişildi.

Sağlamtunç, T. (1991). Kütüphanecilik açısından düşünce özgürlüğü ve sansür. Türk Kütüphaneciliği, 5(3), 93-99. http://www.tk.org.tr/index.php/TK/article/view/1239 adresinden erişildi.

Samek, T. (2001). Introducing Intellectual Freedom Courses into the Canadian LIS Curriculum. Feliciter, (1). https://era.library.ualberta.ca/items/cb1245de-5514-4235-a5d11bb35a37953f/view/3e3eaa79-00ed-4766-a474-a2eeccd0b555/F_47_1_40.pdf adresinden erişildi.

San Jose State University. (2019). Master of Library and Information Science electives courses. https://ischool.sjsu.edu/mlis-electives adresinden erişildi.

Shuman, B. A. (1977). Intellectual freedom courses in graduate library schools. Journal of Education for Librarianship, 18(2), 99-109. https://www.jstor.org/stable/40322532 adresinden erişildi.

Sturges, P. (2016). Intellectual freedom, libraries and democracy, LIBRI, 66(3): 167-177. doi: 10.1515/libri-2016-0040

Toronto University. (2020). Faculty of Information (iSchool) Courses. https://ischool.utoronto.ca/current-students/programs-courses/courses/ adresinden erişildi.

Türk Dil Kurumu (2020). Sansür. https://sozluk.gov.tr/ adresinden erişildi.

Türk Kütüphaneciler Derneği. (2008). Türk Kütüphaneciler Derneği düşünce özgürlüğü bildirgesi. http://37.230.106.98/ kutuphaneciorg/wp-content/uploads/Dusunce_Ozgurlugu_Bildirgesi724x1024.jpg adresinden erişildi.

Türk Kütüphaneciler Derneği. (2010). Türk Kütüphaneciler Derneği mesleki etik ilkeleri. http://kutuphaneci.org.tr/bildirgeler/mesleki-etik-ilkeleri/ adresinden erişildi.

Türk Kütüphaneciler Derneği. (2019). Iffade özgürlüğ̈̈ ve iyi kütüphaneciliğin ilkeleri. http://kutuphaneci.org.tr/bildirgeler/ifade-ozgurlugu-ve-iyi-kutuphaneciligin-ilkeleri/ adresinden erişildi.

University of Alberta. (2020). School of Library and Information Studies MLIS Courses. https://www.ualberta.ca/school-of-library-and-information-studies/study/courses/mliscourses.html adresinden erişildi.

\section{Summary}

The phenomenon of intellectual freedom in societies is supported by the information centres such as libraries, archives and museums where new information is obtained and shared. However, providing an environment suitable for intellectual freedom in information centres is possible if the personnel working at the information centres have a degree of awareness regarding the subject. Information professionals with a low level of awareness regarding intellectual freedom might apply self-censorship without realizing it. In this context, role of the education provided in Information and Records Management departments gains importance for information professionals to provide services in a manner which is more aware, in line with professional principles and neutral. 
Türkiye'deki Bilgi ve Belge Yönetimi Bölümleri Ders Programlarının Düşünce Özgürlüğü Eğitimi Açısından Değerlendirmesi

Evaluation of the Syllabi of Information and Records Management Departments in Turkey in Terms of Intellectual Freedom Education

The purpose of this study is to evaluate syllabi of Information and Records Management Departments in terms of intellectual freedom education. Determining the content and scope of the education given in the departments on intellectual freedom is expected to help the departments to develop their programs on the subject. Within the scope of the research, all course contents in the Bologna Information (ECTS) Packages of the undergraduate and graduate programs of the departments were examined. After the courses related to intellectual freedom are determined ECTS, credits and class information, course objectives and contents, learning and teaching strategies and learning outcomes of the courses related to intellectual freedom, were found from the Bologna information packages of the departments. In addition, interviews with lecturers who are responsible with the teaching of these courses were conducted. In this research which aims to conduct an in-depth analysis of the departments' course contents, objectives, methods and achievements through the use of content analysis method, answers for the below research questions (RQ) were sought:

RQ1. Does the education given on intellectual freedom in Information and Records Management Departments differ according to departments?

RQ2. What are the differences between the departments in the education on intellectual freedom in Information and Records Management Departments?

RQ3. Is there a course directly on intellectual freedom in Information and Records Management programs?

RQ4. Is the issue of intellectual freedom included in the content of ethics courses closely related to intellectual freedom?

RQ5. In which courses, how much and in which context is the issue of intellectual freedom handled?

RQ6. What are the approaches of lecturers about intellectual freedom in Information and Records Management education and the teaching methods they use in the related courses?

The first and second research questions showed that, the education given on the intellectual freedom in the Information and Records Management Departments in Turkey differs in some ways depending on the approach and policies of departments. The expressions about intellectual freedom and the level of participation in the content, objective and achievements of the courses differ according to the departments.

According to the findings obtained within the scope of the third question, the conclusion that there is no mandatory or elective independent course on intellectual freedom included in Information and Records Management undergraduate programs was reached. In post-graduate programs, only Hacettepe University's doctoral program has an independent course titled "Intellectual Freedom and Information Services."

Regarding RQ4, the conclusion that intellectual freedom subjects are generally handled as a part of ethic courses. In Marmara University, there are no courses in which intellectual freedom subjects are handled. It was observed that in most of the departments, subjects such as intellectual freedom, censorship and copyrights are included in professional ethics courses. 
According to Bologna information packages, these subjects are not included in the course contents of Osmaniye Korkut Ata and İstanbul universities.

Within the scope of the fifth question of the research, the content, objective, method and achievements of the courses related to intellectual freedom included in the Bologna information packages were examined. It was determined that intellectual freedom is mostly handled in ethics courses. In the courses, it is usually aimed to teach concepts such as intellectual freedom, copyrights and censorship. Creating an awareness regarding intellectual freedom is not among the objectives of the courses in any of the departments. According to the Bologna information packages of Çankırı Karatekin, Kastamonu and Istanbul universities, there are no objectives in courses aimed towards intellectual freedom. The methods and techniques of professional ethics courses are generally set as lecture and discussion. It was observed that concepts regarding intellectual freedom are not generally given place within the achievements of the courses.

As a result of the interviews conducted with the lecturers within the scope of RQ6, it was concluded that all lecturers deem intellectual freedom important. The lecturers consider that intellectual freedom should be handled throughout all courses in the curriculum, and not just in ethics courses. According to the lecturers who were interviewed, students develop an awareness regarding intellectual freedom within the scope of the courses. The lecturers are generally of the thought that intellectual freedom should have its independent course.

In conclusion, hypothesis generated as "education for intellectual freedom in the Information and Records Management departments in Turkey differs depending on the approach (policies) of the departments " was accepted. In this context, some suggestions have been presented to improve the education on intellectual freedom. 